\title{
Kinetic Study of the Acid Hydrolysis of Parthenium hysterophorus L. for xylose yield in the Production of Lignocellulosic ethanol
}

\author{
Ghosh Swati ${ }^{1}$, Haldar $\mathrm{S}^{2}$, Shubhaneel $\mathrm{N}^{3}$, Ganguly $\mathrm{A}^{4}$, Chatterjee P. $\mathrm{K}^{4 *}$ \\ ${ }^{I}$ Department of Chemistry, Institute of Engineering and Industrial Technology, Durgapur - 713212, India \\ ${ }^{2}$ Department of Chemical Engineering , National Institute of Technology, Durgapur-713209, India \\ ${ }^{3}$ Periyar University, Salem, India \\ ${ }^{4}$ Thermal Engineering Group, Central Mechanical Engineering Research Institute, Durgapur - 713209, India
}

\begin{abstract}
Parthenium hysterophorus L commonly known as Parthenium weed is one of the seven obnoxious weed in the world. Being a lignocellulosic biomass, with a composition of Lignin: 13.9\%; Hemicellulose: $21.01 \%$ and Cellulose: $27.8 \%$, it may be considered as the potential source of fuel ethanol production though pretreatment, saccharification and fermentation route. In the present work, efforts have been made to increase the yield of xylose during the hydrolysis process. Hydrolysis of Parthenium hysterophorus was carried out with $1 \%, 3 \%$ \& $5 \% \mathrm{H}_{2} \mathrm{SO}_{4}$ solutions. Each set of biomass was allowed to soak for $1 \mathrm{~h} \& 2 \mathrm{~h}$ for each acid concentration. Finally the substrates were treated for up to $10 \mathrm{~min}$ in the temperature range of $190-230^{\circ} \mathrm{C}$. The xylose yield has been studied for every set of parameters. The maximum value of xylose yield obtained is $46.41 \mathrm{mg} / \mathrm{g}$ of dry Parthenium, when hydrolysed with $5 \% \mathrm{H}_{2} \mathrm{SO}_{4}$ at a temperature of $230^{\circ} \mathrm{C}$ in $2 \mathrm{~h}$ soaking time and 10 min treatment time. The values of kinetic rate constants show the adherence to Arrhenius relationship with significant changes in the concentration of acid and soaking period.
\end{abstract}

Keywords: Acid Hydrolysis, Ethanol, Lignocellulose, Parthenium pretreatment, Xylose.

\section{Introduction}

Energy consumption has increased drastically during the last century since more countries have become industrialized to meet up increasing public demand. Crude oil is one of the major resources to meet the increased energy demand. Campbell and Laherrere (1998) investigated to estimate the current known crude oil reserves and the reserves as yet undiscovered and predicted that annual global oil production would decline from the current 25 billion barrels to approximately 5 billion barrels in 2050 . So it is essential to find out the alternative energy sources. Unlike fossil fuels, ethanol is a renewable energy source produced though fermentation of sugars. Ethanol can be used as a partial gasoline replacement. Fuel ethanol, produced from corn, has been used in gasohol or oxygenated fuels since the 1980s. These gasoline fuels contain up to $10 \%$ ethanol by volume.

A potential source for low-cost ethanol production is to utilize lignocellulosic materials such as crop residues, grasses, sawdust, wood chips, and solid animal waste. Extensive research has been done on conversion of lignocellulosic materials to ethanol in the last two decades. The lignocellulosic conversion involves two processes: hydrolysis of cellulose in the lignocellulosic materials to fermentable reducing sugars, and fermentation of the sugars to ethanol. The hydrolysis is usually governed by cellulase enzymes catalyst and the fermentation is carried out by yeasts or bacteria. The factors on which the hydrolysis depends are porosity (accessible surface area) of the materials, cellulose fiber crystallinity, and lignin and hemicellulose content of the lignocellulosic biomass. The presence of lignin and hemicelluloses hinder the accessibility of cellulase enzymes to cellulose, thus reduces the efficiency of the hydrolysis. The effect of pretreatment of lignocellulosic materials has been recognized for a long time. The purpose of the pretreatment is to remove lignin and hemicellulose, reduce cellulose crystallinity, and increase the porosity of the materials. Pretreatment must meet the following requirements: (1) improve the formation of sugars or the ability to subsequently form sugars by enzymatic hydrolysis; (2) avoid the degradation or loss of carbohydrate; (3) avoid the formation of by products inhibitory to the subsequent hydrolysis and fermentation processes; and (4) be cost-effective. Physical, physicochemical, chemical, and biological processes have been used for pretreatment of lignocellulosic materials [1].

Parthenium hysterophorus L commonly known as Parthenium weed, also known as congress grass, carrot weed, star weed, feverfew, white top, chatak chandani, bitter weed, ramphool, garghas depending on the country and area infested. This weed causes allergic respiratory problems, contact dermatitis, mutagenicity in human being and livestock. Biodiversity and crop production is remarkably reduced owing to its allelopathy and aggressiveness. The pollen is also reported to have allelopathic activity and has inhibited development of fruit on brinjal, tomato, chilli, when artificially disted on stigatic surface of these plants [2].

Parthenium hysterophorus is able to grow on a wide range of soil types ranging from sandy to heavy clays but growth is better in later type of soil. It occurs in areas with summer rainfall greater than $500 \mathrm{~mm}$ per 
Kinetic Study of the Acid Hydrolysis of Parthenium hysterophorus L. for xylose yield in the

annum. Germination favours at temperatures between $10{ }^{\circ} \mathrm{C}$ and $25^{\circ} \mathrm{C}$. Parthenium weed colonises new areas rapidly by means of relatively high numbers of seeds, producing one lakh seeds per plant. Dispersal of seed takes place via vehicle, water, animals, farm machinery and wind. Disturbed habitats such as roadsides and railway tracks, stockyards, buildings surroundings and fallow agricultural land are particularly suitable for growing P hysterophorus due to a lack of interspecies competition [3].

The waste land weed parthenium hysterophorus has been recorded growing and colonising naturally since centuries in Mexico, Cuba, North and South America, West Indies, Australia, Taiwan, Southern China, pacific island, East and South Africa, Asia, Oceania and Canada. Till 1977 the weed was not considered as the world's worst weed, but within the last decade it has become one of the seven most dreaded weeds of the world. Parthenium weed was first noted in India near Pune in Maharashtra State in 1951. By 1972 it had spread into the most of the western States from Kashmir in the north to Kerala in the south and is now spreaded almost thoughout the subcontinent with abnormal density [2].

The objective of this work is to apply a simple and reliable pretreatment process with dilute acid hydrolysis for the conversion of dry parthenium to xylose. The parthenium used in this study has a composition of $27.8 \%$ cellulose, $21.01 \%$ hemicellulose, $13.9 \%$ lignin as determined in the laboratory. Estimations of xylose which is a major fermentable sugar have been performed by spectrophotometer. Moreover, different parameters like treatment temperature, treatment time, concentration of the medium, soaking time of the dried biomass have been considered and detailed studies were carried out with parthenium hysterophorus to establish the variation of xylose yield.

\subsection{Preparation of Parthenium for experiment}

Materials and Methods

Fresh Parthenium with long stem was collected from local area. The Parthenium was thoroughly washed several times with tap water to remove adhering dirt, chopped into small pieces of size 1-2 cm (approx), and further grounded to even smaller particles of size 3-5 mm (approx), and finally dried in a hot air oven at 106 ${ }^{\circ} \mathrm{C}$ for $6 \mathrm{~h}$. The dried material was stored at room temperature until used.

\subsection{Preparation of hemicellulose acid hydrolysate}

$1 \mathrm{~g}$ of dried Parthenium was mixed with $1 \%, 3 \%$ \& 5\% concentration sulfuric acid respectively to a final volume of $10 \mathrm{~mL}$. The mixtures were soaked for $1 \mathrm{~h}$ and $2 \mathrm{~h}$ for each set of sample. The acid hydrolysis reactions were carried out in the temperature range of $190{ }^{\circ} \mathrm{C}, 210^{\circ} \mathrm{C}$ and $230{ }^{\circ} \mathrm{C}$ for a treatment time of $2 \mathrm{~min}, 6 \mathrm{~min}$ and $10 \mathrm{~min}$, after which the hydrolysate was cooled down to room temperature. The hydrolysate was filtered using Wattman paper no.1 to remove the unhydrolysed material and solid residue. The filtrate was collected and subjected to analyze the xylose content.

\subsection{Determination of xylose content by Phloroglucinol assay}

Xylose content was determined using the Phloroglucinol assay [4-5] with the hydrolysate obtained from acid hydrolysis. The colouring reagent mixture was heated in water bath and rapidly cooled to room temperature before measuring in a Spectrophotometer at $554 \mathrm{~nm}$.

\subsection{Benzoic acid solution preparation}

$0.2 \mathrm{~g}$ of benzoic acid is mixed in $100 \mathrm{~mL}$ of distilled water, which was preheated at $60{ }^{\circ} \mathrm{C}, \&$ mixed well, then cooled \& filtered to store the solution.

\subsection{D-xylose preparation}

D-xylose was dissolved in benzoic acid to prepare a xylose solution. $0.05 \mathrm{~g}$ of D-xylose were mixed with $10 \mathrm{~mL}$ of benzoic acid to prepare xylose solution $(10 \mathrm{~g} / \mathrm{L})$ though the following methods.

i. $\quad 100 \mathrm{~mL}$ of distilled water is heated.

ii. $\quad 0.2 \mathrm{mg}$ of benzoic acid GR (Guaranted Reagent) is added slowly to the water.

iii. The solution is mixed thoroughly \& filtered to remove the benzoic acid crystals.

iv. Stock solution of D-xylose is made by adding $0.05 \mathrm{~g}$ of D-xylose in $10 \mathrm{~mL}$ benzoic acid solution.

From this stock, D-xylose solution of $0.4 \mathrm{~g} / \mathrm{L}, 0.8 \mathrm{~g} / \mathrm{L}, 1.2 \mathrm{~g} / \mathrm{L}, 1.6 \mathrm{~g} / \mathrm{L}$ and $2.0 \mathrm{~g} / \mathrm{L}$ concentration Dxylose was prepared for the standard curve measured at $554 \mathrm{~nm}$ in spectrophotometer.

\subsection{Phloroglucinol solution}

To make $100 \mathrm{~mL}$ of Phloroglucinol solution, $100 \mathrm{~mL}$ of glacial acetic acid and $0.50 \mathrm{~g}$ of phloroglucinol were mixed together. 
Kinetic Study of the Acid Hydrolysis of Parthenium hysterophorus L. for xylose yield in the

\subsection{Measuring of Xylose}

To measure xylose $200 \mu \mathrm{L}$ of sample was mixed with $5 \mathrm{~mL}$ of phloroglucinol solution for making the final mixture. The samples were heated at $100{ }^{\circ} \mathrm{C}$ for $4 \mathrm{~min}$ and cooled to room temperature. The samples were then measured with spectrophotometer and the absorbance was recorded at $554 \mathrm{~nm}$.

\subsection{Preparation of blank}

$2 \mathrm{~mL}$ of benzoic acid was added to $300 \mathrm{~mL}$ of $\mathrm{ZnSO}_{4}, 300 \mathrm{~mL}$ of $\mathrm{NaOH}, \& 500 \mathrm{~mL}$ of concentrated $\mathrm{HCL}$, then $5 \mathrm{~mL}$ of phloroglucinol solution was added to make the final mixture. The samples were heated at $100{ }^{\circ} \mathrm{C}$ for $5 \mathrm{~min}$ and cooled to room temperature.

\subsection{Governing equation}

In mid 1940s, Saeman [6] modelled the first-order homogeneous kinetics of wood cellulose saccharification and it became the pioneer model for describing sugar degradation followed by hemicellulose hydrolysis. Monophasic hydrolysis of hemicellulose is described [7] in a very simple way as :

$$
\begin{aligned}
& \text { Hemicellulose } \\
& \quad \mathrm{k}_{1} \\
& \quad \text { Xylan }]
\end{aligned}
$$

Where, $\mathrm{k}_{1}, \mathrm{k}_{2} \& \mathrm{k}_{3}$ are the reaction rate constants of the respective reactions. The governing equations for hemicelluloses hydrolysis [7] are shown in Table - 1.

\section{Table 1}

$$
\begin{aligned}
& \text { Monophasic Hydrolysis } \\
& \frac{d H}{d t}=-\mathrm{k}_{1} \mathrm{H} \\
& \frac{d O}{d t}=\mathrm{k}_{1} \mathrm{H}-\mathrm{k}_{2} \mathrm{O} \\
& \frac{d X}{d t}=\mathrm{k}_{2} \mathrm{O}-\mathrm{k}_{3} \mathrm{X} \\
& \frac{d D}{d t}=\mathrm{k}_{3} \mathrm{X}
\end{aligned}
$$

Where, $[\mathrm{H}],[\mathrm{O}]$ and $[\mathrm{X}]$ signifies the concentration of hemicellulose, oligomers and xylose respectively.

\section{Results and discussion:}

Reported work in the field of parthenium conversion to ethanol is limited. The present work emphasized on the kinetics of xylose conversion from hemicelluloses derived from Parthenium hysterophorus L. Successful bioconversion of lignocelluloses from locally available Parthenium to xylose production has been achieved by using dilute acid hydrolysis process. Hydrolysis of Parthenium by dilute acid yields mixture of sugars with xylose as a major component [8-10].

The effects of varying soaking time, treatment time, treatment temperature and concentration of sulphuric acid on the xylose yield from hemicelluloses derived from Parthenium hysterophorus $\mathrm{L}$ have been investigated and represented through Fig. 1-6. 


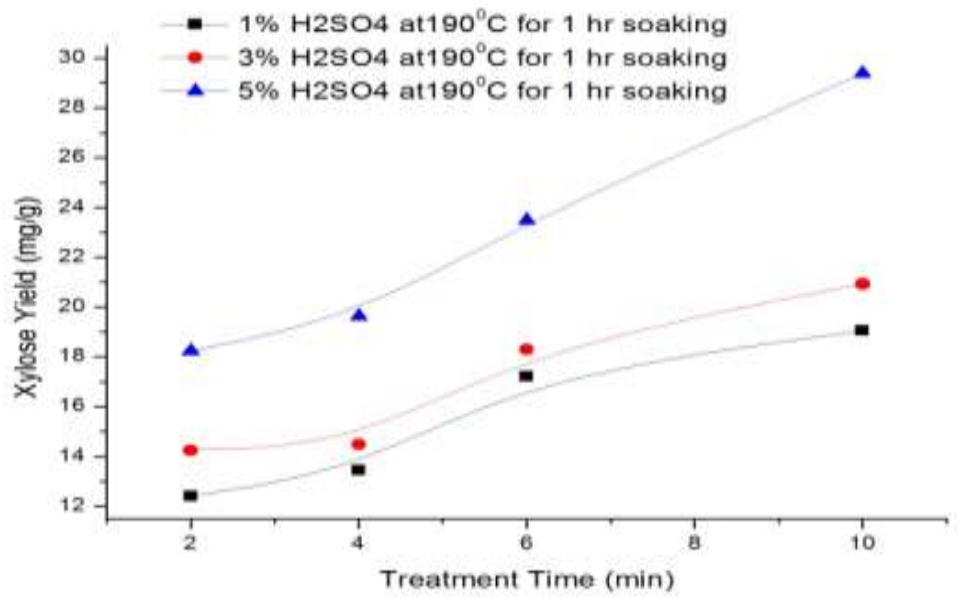

Fig. 1: Xylose yield with change in treatment time and concentration of sulphuric acid at treatment temperature of $190{ }^{\circ} \mathrm{C}$ and soaking time of $1 \mathrm{~h}$

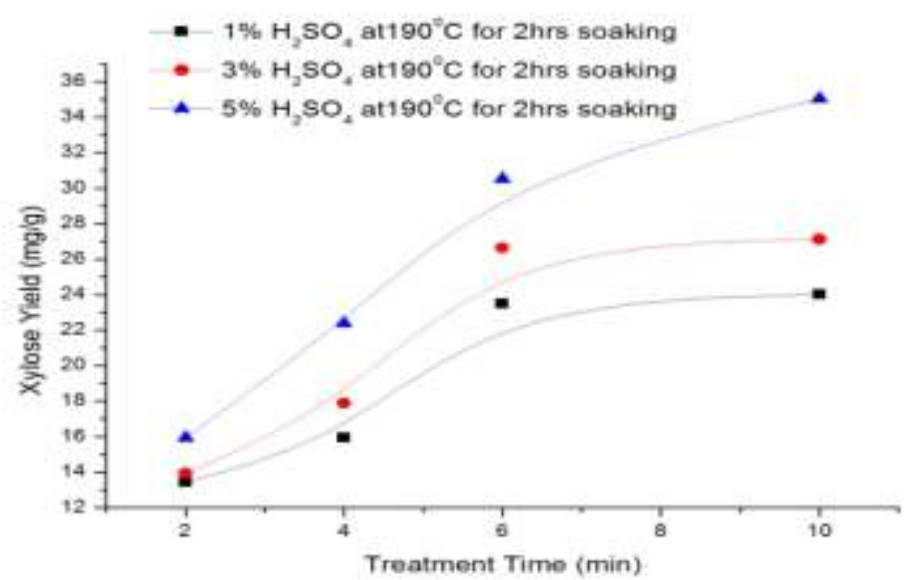

Fig. 2: Xylose yield with change in treatment time and concentration of sulphuric acid at treatment temperature of $190{ }^{\circ} \mathrm{C}$ and soaking time of $2 \mathrm{~h}$

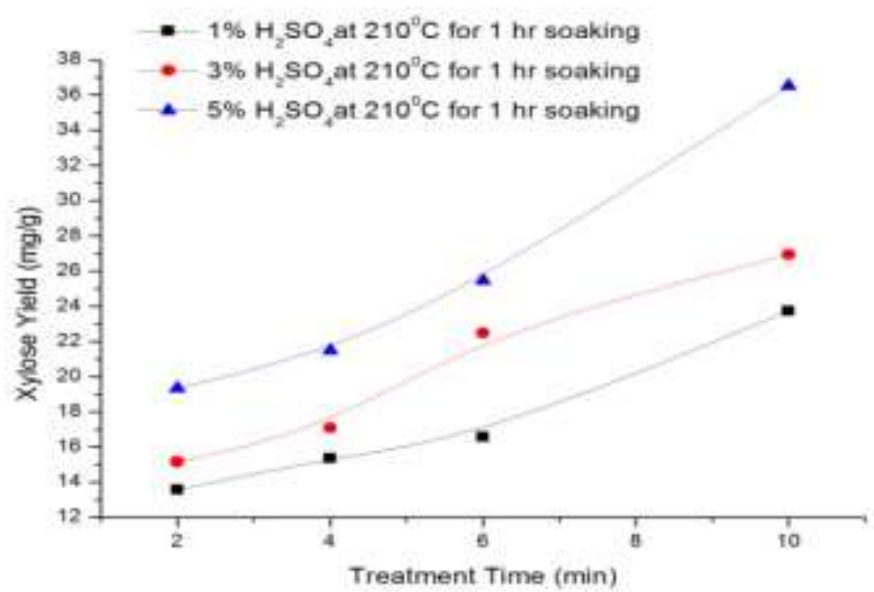

Fig. 3: Xylose yield with change in treatment time and concentration of sulphuric acid at treatment temperature of $210{ }^{\circ} \mathrm{C}$ and soaking time of $1 \mathrm{~h}$ 


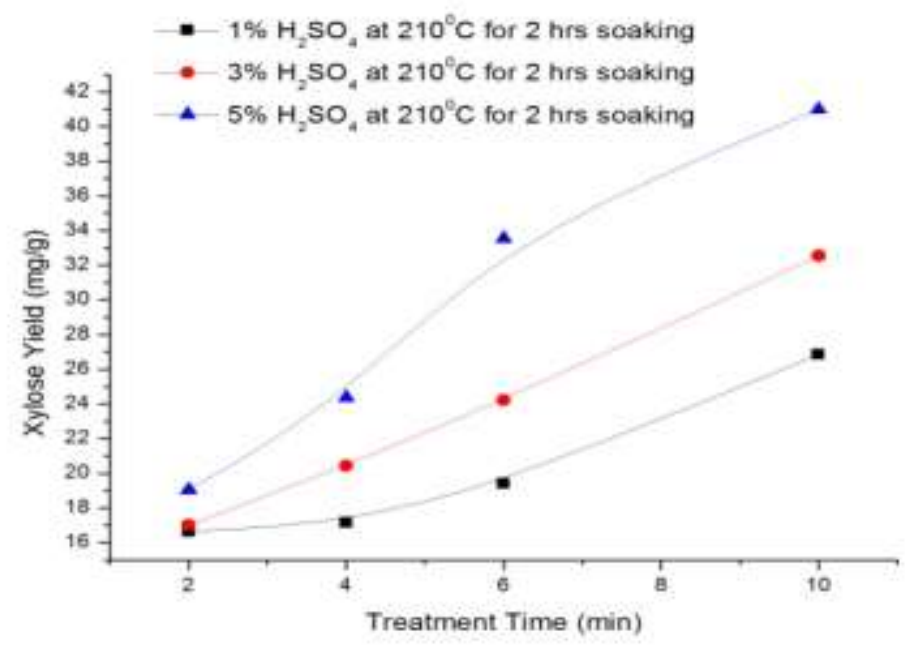

Fig. 4: Xylose yield with change in treatment time and concentration of sulphuric acid at treatment temperature of $210{ }^{\circ} \mathrm{C}$ and soaking time of $2 \mathrm{~h}$

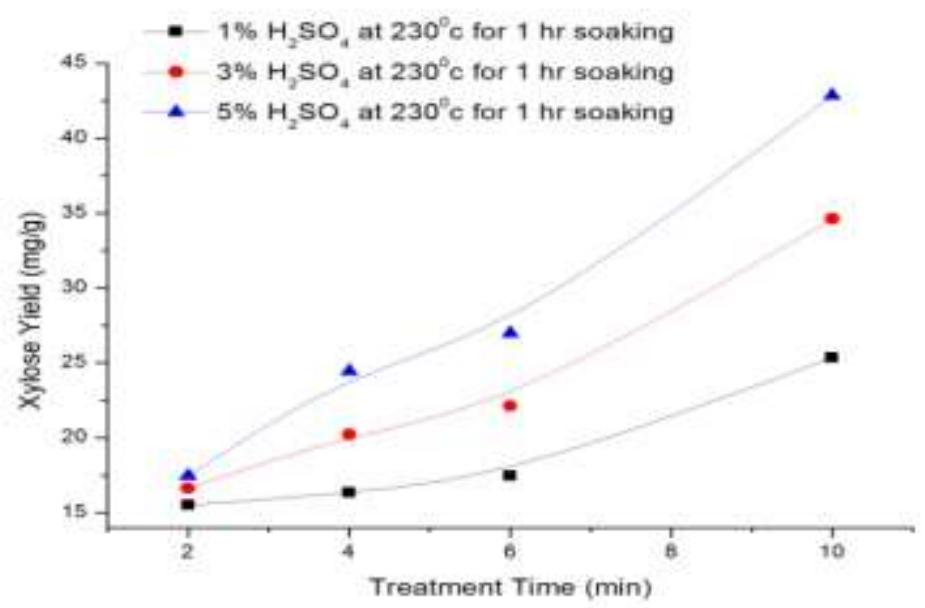

Fig. 5: Xylose yield with change in treatment time and concentration of sulphuric acid at treatment temperature of $230{ }^{\circ} \mathrm{C}$ and soaking time of $1 \mathrm{~h}$

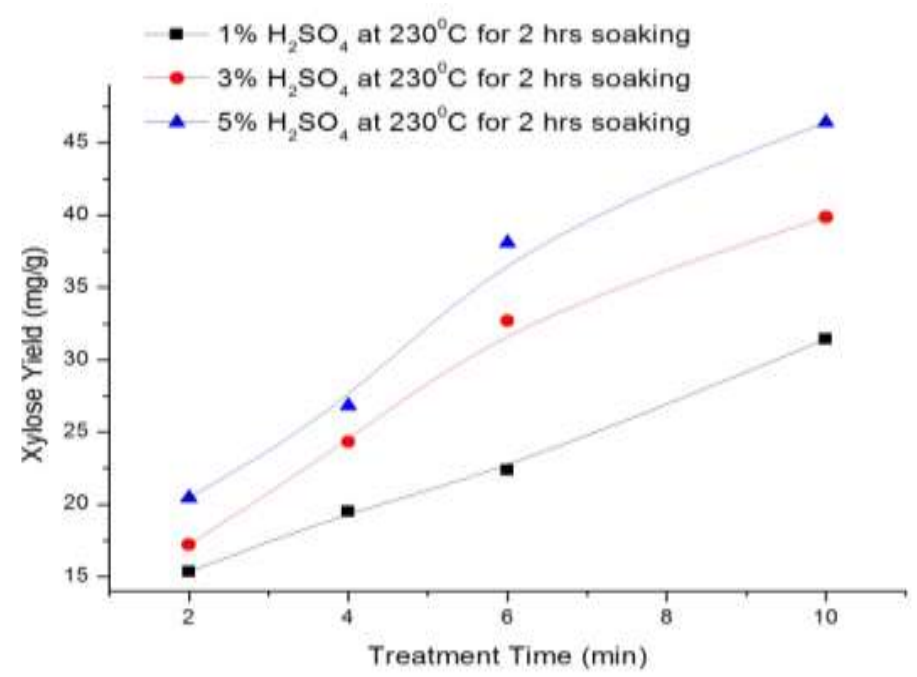

Fig. 6: Xylose yield with change in treatment time and concentration of sulphuric acid at treatment temperature of $230{ }^{\circ} \mathrm{C}$ and soaking time of $2 \mathrm{~h}$ 
Kinetic Study of the Acid Hydrolysis of Parthenium hysterophorus L. for xylose yield in the

It has been noticed that an increase in acid concentration from $1 \%$ to $5 \%$ leads to increase in the xylose yield at a particular soaking time, treatment time and treatment temperature. The maximum xylose yield from dried Parthenium was found up to $46.41 \mathrm{mg} / \mathrm{g}$, when the acid hydrolysate was soaked for $2 \mathrm{~h}$ and kept at the furnace temperature of $230{ }^{\circ} \mathrm{C}$ for $10 \mathrm{~min}$. The generation of furfural, a by-product of xylose degradation [11] as a consequence of acid hydrolysis is to be kept in mind during the pretreatment process. The rate of degradation depends on temperature and concentration of sulfuric acid [12]. The results of above investigations do not depict any significant degradation of xylose obtained through hydrolysis of Parthenium hysterophorus $\mathrm{L}$.

The rate constant $\mathrm{k}$ for the dilute acid hydrolysis of Parthenium hysterophorus $\mathrm{L}$ increases with the temperature and follows the Arrhenius law in the form of $\mathrm{k}=\mathrm{Ae}^{(-\mathrm{E} / \mathrm{RT})}$, where $\mathrm{A}$ is the pre exponential factor and depends on the concentration. The ' $\mathrm{A}$ ' value can be determined from the intercepts of Arrhenius curves with the y-axis. The Arrhenius curves for the present process are shown in Fig. 7.

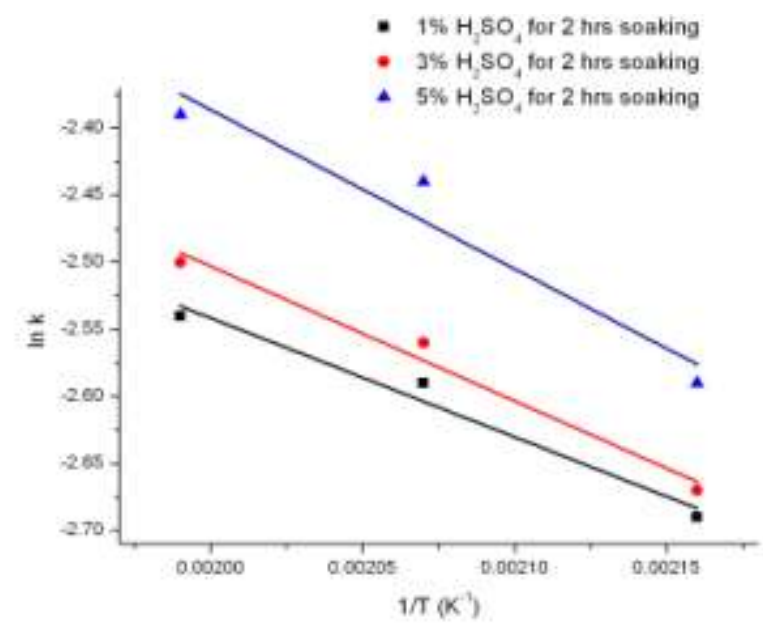

Fig. 7: Arrhenius plot for hydrolysis of Parthenium hysterophorus with sulphuric acid in the temperature range $190-230{ }^{\circ} \mathrm{C}$

Values of reaction rate constants at different temperature, soaking time for different soaking conditions are shown in Table 2 and Table 3.

Table 2: Rate constants for different $\mathrm{H}_{2} \mathrm{SO}_{4}$ concentrations with $1 \mathrm{~h}$ Soaking period

\begin{tabular}{cccc}
$\mathrm{T}(\mathrm{K})$ & $\mathrm{k}_{1 \%}\left(\min ^{-1}\right)$ & $\mathrm{k}_{3 \%}\left(\mathrm{~min}^{-1}\right)$ & $\mathrm{k}_{5 \%}\left(\min ^{-1}\right)$ \\
463 & 0.058 & 0.061 & 0.067 \\
483 & 0.072 & 0.076 & 0.091 \\
503 & 0.074 & 0.089 & 0.094 \\
\hline
\end{tabular}

Table 3: Rate constants for different $\mathrm{H}_{2} \mathrm{SO}_{4}$ concentrations with $2 \mathrm{~h}$ Soaking period

\begin{tabular}{cccc}
\hline $\mathrm{T}(\mathrm{K})$ & $\mathrm{k}_{1 \%}\left(\mathrm{~min}^{-1}\right)$ & $\mathrm{k}_{3 \%}\left(\min ^{-1}\right)$ & $\mathrm{k}_{5 \%}\left(\mathrm{~min}^{-1}\right)$ \\
463 & 0.068 & 0.069 & 0.075 \\
483 & 0.075 & 0.077 & 0.087 \\
503 & 0.079 & 0.082 & 0.092 \\
\hline
\end{tabular}

It has been observed that the soaking of Parthenium substrate in dilute acid at ambient temperature (27 ${ }^{\circ} \mathrm{C}$ ) before its hydrolysis treatment in the temperature range of $190-230^{\circ} \mathrm{C}$ also plays an effective role in the xylose production in addition to concentration of sulphuric acid. The reaction rate increases with the soaking period as it increases from $1 \mathrm{~h}$ to $2 \mathrm{~h}$.

\section{Conclusion:}

The reports on the study of hydrolysis of parthenium hysterophorus with a view to produce ethanol are limited. Hydrolysis was carried out with $1 \%, 3 \% \& 5 \% \mathrm{H}_{2} \mathrm{SO}_{4}$ solutions in the temperature range of 190 to 230 ${ }^{\circ} \mathrm{C}$ and treatment time upto $10 \mathrm{~min}$ and soaking time of $1 \mathrm{~h}$ and $2 \mathrm{~h}$. The xylose yield has been studied for every set of parameters. From experimental results it has been found that xylose yield increases with increase in the treatment temperature of the biomass inside the furnace at a particular soaking time and acid concentration. The xylose yield also increases with increase in acid concentrations for a specific soaking time and treatment time in furnace. It is observed that the soaking time at ambient temperature before the actual hydrolysis reaction in the furnace plays an important role to enhance the yield of xylose. The maximum value of xylose yield obtained is 
Kinetic Study of the Acid Hydrolysis of Parthenium hysterophorus L. for xylose yield in the around $46.41 \mathrm{mg} / \mathrm{g}$ of dry Parthenium, when hydrolysed with $5 \% \mathrm{H}_{2} \mathrm{SO}_{4}$ at a temperature of $230{ }^{\circ} \mathrm{C}$ with $2 \mathrm{~h}$ soaking time and $10 \mathrm{~min}$ treatment time. The reaction rate for hydrolysis is more for higher soaking period. The present work will encourage the researchers to explore the potential of one of the most obnoxious weed, Parthenium Hysterophorus L for the generation of green fuel ethanol. Regression of kinetic data may be taken up as future work for optimization of parameters affecting the production of xylose from parthenium hysterophorus $\mathrm{L}$.

\section{Acknowledgements:}

Authors wish to thank Director, CSIR Central Mechanical Engineering Research Institute, Durgapur for his constant support, encouragement and permission to publish this paper.

\section{References:}

[1] Y. Sun and J. Cheng, Hydrolysis of lignocellulosic materials for ethanol production: a review, Bioresource Technology 83, 2002, $1-11$.

[2] M. Mahadevappa, Parthenium hysterophorus. L - A Dreaded Weed, International Parthenium research News, 1(1), 2008.

[3] A. J. Mcconnachie, L. W. Strathie, W. Mersie, L. Gebrehiwot, K. Zewdie, A. Abdurehim, B. Abrha, T. Arrrraya, F. Asaregew, F. Assefa, R. Gebre-Tsadik, L. Nigatu, B. Tadesse and T. Tana, Current and potential geographical distribution of the invasive plant Parthenium hysterophorus (Asteraceae) in eastern and southern Africa, Weed Research, 51(1), 2011, 71-84.

[4] T. J. Eberts, R. H. Sample, M. R. Glick and G. H. Ellis, A simplified colorimetric micromethod for xylose in serum or urine, with phloroglucinol, Clin Chem. 25, 1979, 1440-1443.

[5] S. L. Johnson Bliss M, Mayersohn and K. A. Conrad, Phloroglucinol-based colorimetry of xylose in plasma and urine compared with a specific gas-chomatographic procedure, Clin Chem. 30, 1984, 1571-1574

[6] J. F. Saeman, Kinetics of wood saccharificarion hydrolysis of cellulose and decomposition of sugar in dilute acid at high temperature, Industrial and Engg. Chem. $\quad 37(1), 1945,43-52$.

[7] C. Pronyk and G. Mazza, Kinetic Modeling of Hemicellulose Hydrolysis from Triticale Straw in a Pressurized Low Polarity Water Flow-Though Reactor, Ind Eng Chem. 49, 2010, 6367 - 6375.

[8] I. C. Roberto, I. M. Mancilha, C. A. Souza, M. G. A. Felipe, S. Sato and H. F. Castro, Evaluation of rice straw hemicellulose hydrolysate in the production of xylitol by Candida guilliermondii, Biotechnol Lett. 16, 1994,1211-1216.

[9] R. Elander and T. Hsu, Processing and economic impacts of biomass delignification for ethanol production, Appl Microbiol Biotechnol, 51, 1995, 463-478.

[10] Jr A. Pessoa, I. M. Mancilha and S. Sato, Acid hydrolysis of hemicellulose from sugarcane bagasse, Braz J Chem Eng., 14(3), 1997, doi: 10.1590/S0104-66321997000300-013.

[11] M. Ackerson, M. Ziobro and J. L. Gaddy, Two-stage acid hydrolysis of biomass, Biotechnol Bioeng Symp, 11, 1981, 103112 .

[12] G. Gonzales, J. Lopes-Santin, G. Caminal and C. Sola, Dilute acid hydrolysis of wheat straw hemicellulose at moderate temperature: a simplified kinetic model, Biotechnol Bioeng, 28, 1986, 288-293. 